\title{
Studi Kuantitas Air Buangan Kampus Universitas Andalas Limau Manis Padang
}

\author{
Puti Sri Komala $^{1}$, Yenni Ruslinda ${ }^{2}$, Juwita Zurienra ${ }^{3}$ \\ 1,2,3 Jurusan Teknik Lingkungan Fakultas Teknik Universitas Andalas, Padang \\ *Koresponden email: putisrikomala@eng.unand.ac.id
}

Diterima: 8 Maret 2020

Disetujui: 23 Maret 2020

\begin{abstract}
In this study, the quantity of wastewater from the existing facilities at the Andalas University Campus was carried out. The measured wastewater consists of grey water, black water, and specific wastewater. The wastewater was classified based on its activities, namely dormitories, lecture room, student facilities, offices, religious facilities, cafeterias, sports facilities, laboratories, and campus bus pools. The sampling method used was the bucket method. Grey water sampling was carried out on regular days (MondayThursday), worship days (Friday), and holidays (Saturday and Sunday), while specific wastewater and black water were measured on regular days. Peak hours occur at 12.00-14.00 except in the dormitory at 06.00-08.00 and cafeteria at 10.00-11.00. The peak factor of used water ranges from 1.56 to 3.13. From the measurement results obtained the wastewater from dormitory wastewater of $212.8 \mathrm{~m}^{3} / \mathrm{day}$; lecture building $491 \mathrm{~m}^{3} /$ day; student facilities $32.4 \mathrm{~m}^{3} /$ day; offices $245.4 \mathrm{~m}^{3} /$ day; worship $50.4 \mathrm{~m}^{3} /$ day; cafeteria $109.2 \mathrm{~m}^{3} /$ day; sports facilities $8.7 \mathrm{~m}^{3} /$ day; laboratory $282 \mathrm{~m}^{3} /$ day; corral $27 \mathrm{~m}^{3} /$ day; and pool bus 34.7 $\mathrm{m}^{3} /$ day respectively. The total wastewater from Unand Limau Manis Campus is $1,439.6 \mathrm{~m}^{3} / \mathrm{day}$. The wastewater composition consists of, grey water $812.3 \mathrm{~m}^{3} /$ day $(52.67 \%)$, specific wastewater $343.8 \mathrm{~m}^{3} /$ day $(23.45 \%)$ and $337.5 \mathrm{~m}^{3} /$ day $(23.88 \%)$ black water.
\end{abstract}

Keywords: Andalas University, black water, campus facilities, grey water, wastewater quantity

\begin{abstract}
Abstrak
Pada penelitian ini dilakukan pengukuran kuantitas air buangan pada fasilitas yang ada di Kampus Universitas Andalas. Air limbah yang diukur terdiri air bekas, air kotor, dan air buangan khusus. Air buangan diklasifikasikan berdasarkan aktivitasnya, yaitu asrama, ruang perkuliahan, fasilitas kemahasiswaan, perkantoran/birokrasi, sarana ibadah, kafetaria, sarana olahraga, laboratorium, dan pool bus kampus. Metode sampling yang digunakan adalah bucket method. Sampling air bekas dilakukan pada hari reguler (Senin-Kamis), hari khusus (Jumat), dan hari libur (Sabtu dan Minggu), sedangkan air buangan khusus dan air kotor dilakukan pada hari reguler. Jam puncak terjadi pada pukul 12.00-14.00 kecuali di asrama pukul 06.00-08.00 dan kafetaria pukul 10.00-11.00. Faktor puncak air bekas berkisar pada 1,56-3,13. Dari hasil pengukuran diperoleh debit rata-rata air bekas asrama $212,8 \mathrm{~m}^{3} / \mathrm{hari}$; gedung perkuliahan $491 \mathrm{~m}^{3} /$ hari; fasilitas kemahasiswaan $32,4 \mathrm{~m}^{3} /$ hari; perkantoran $245,4 \mathrm{~m} 3 /$ hari; sarana ibadah 50,4 m3/hari; kafetaria 109,2 m3/hari; sarana olahraga $8,7 \mathrm{~m}^{3} /$ hari; laboratorium $282 \mathrm{~m}^{3} /$ hari; kandang 27 $\mathrm{m}^{3} /$ hari; pool bus $34,7 \mathrm{~m}^{3} /$ hari. Total air buangan Kampus Unand Limau Manis adalah sebesar 1.439,6 $\mathrm{m} 3 /$ hari, dengan komposisi air buangan yaitu, air bekas $812,3 \mathrm{~m}^{3} /$ hari $(52,67 \%)$, air buangan khusus $343,8 \mathrm{~m}^{3} /$ hari $(23,45 \%)$ dan air kotor $337,5 \mathrm{~m}^{3} /$ hari $(23,88 \%)$.
\end{abstract}

Kata kunci: air bekas, air kotor, kuantitas air buangan, fasilitas kampus, Universitas Andalas

\section{Pendahuluan}

Universitas Andalas (Unand) dengan jumlah sivitas akademika sekitar 25.000 orang merupakan salah satu universitas terbesar di Sumatra Barat [1]. Universitas ini memiliki berbagai jenis aktivitas, yaitu aktivitas perkantoran, perkuliahan, perniagaan, rumah makan/kafetaria, dan asrama. Menurut Keputusan Menteri Negara Lingkungan Hidup Nomor 68 Tahun 2016, air buangan Kampus Unand termasuk dalam kategori air buangan domestik [2]. Selain aktivitas domestik, Kampus Unand juga memiliki laboratorium yang menghasilkan air buangan dengan karakteristik yang berbeda dengan air buangan domestik karena sifatnya yang berbahaya meskipun kuantitas air buangan yang dihasilkan lebih kecil. Pembangunan fisik di Kampus Unand Limau Manis saat ini terus berkembang, terlebih dengan adanya perencanaan pembangunan rumah sakit dan pemindahan beberapa fakultas ke kampus Limau 
Manis. Sejalan dengan perkembangan tersebut, kuantitas air buangan yang dihasilkan pun akan meningkat.

Seperti pada umumnya penanganan limbah domestik di negara berkembang, penanganan limbah domestik di Unand masih menggunakan sistem individual yaitu septic tank. Pengolahan limbah dengan septik tank hanya digunakan untuk mengolah air buangan yang berasal dari air kotor (black water), sedangkan air yang berasal dari floor drain, wastafel, dan sink dikenal dengan air bekas (grey water) hanya dialirkan begitu saja ke drainase. Ref. [3] melaporkan bahwa penyisihan BOD dari septic tank menghasilkan effisiensi sebesar 62,15\%, dengan hasil BOD efluent 314,84 mg/L. Meskipun jumlah BOD mengalami penurunan, tetapi masih melebihi standar baku mutu yang ditetapkan KepmenLH Nomor 68 Tahun 2016 yaitu $100 \mathrm{mg} / \mathrm{L}$. Ref [4] juga mengungkapkan bahwa penyisihan septic tank tipikal berada di rentang 30-50\% dengan efluen BOD 118-189 mg/L untuk domestik dan 101-800 mg/L untuk restoran.

Penelitian-penelitian tersebut menunjukkan bahwa konsentrasi efluen air kotor hasil pengolahan on-site masih melebihi standar baku mutu, ditambah dengan air bekas yang langsung dibuang ke saluran drainase juga berkontribusi tinggi terhadap pencemaran lingkungan. Oleh karena itu, dibutuhkan datadata baik kualitas maupun kuantitas air buangan untuk pengelolaan air buangan secara manyeluruh. Datadata ini juga diharapkan dapat melengkapi data-data yang diperlukan untuk membuat perencanaan pengelolaan air buangan Kampus Unand secara terpadu. Berdasarkan penjelasan tersebut, dalam penelitian ini dilakukan studi kuantitas air buangan untuk berbagai aktivitas yang ada di Kampus Unand. Penelitian mencakup perhitungan kuantitas air bekas (grey water), air buangan khusus, dan air kotor (black water), fluktuasi air bekas, dan faktor puncak air buangan.

\section{Metode Penelitian}

\section{Tempat dan Waktu Penelitian}

Penelitian ini dilaksanakan dari bulan November sampai bulan Desember 2012 yang berlokasi di gedung-gedung perkantoran, perkuliahan, laboratorium, fasilitas pencucian bus, kantin, sarana olah raga dan sarana ibadah yang ada di Universitas Andalas (Unand), Padang.

\section{Klasifikasi Air Buangan}

Air buangan yang diukur diklasifikasikan atas empat golongan, yaitu (1) berdasarkan jenisnya, (2) aktivitas gedung, (3) berdasarkan hari, dan (4) berdasarkan debit. Berdasarkan jenis air buangan terbagi tiga, yaitu (1) air bekas (grey water) yaitu air buangan yang dihasilkan dari air bekas berwudhu, cuci piring, floor drain, dan wastafel; (2) air buangan khusus yaitu air buangan yang mengandung zat-zat berbahaya, berasal dari laboratorium, kandang, dan pool bus kampus; dan (3) air kotor (black water) yaitu air buangan yang berasal dari kegiatan toilet.

Air buangan juga dibagi berdasarkan aktivitas gedung. Dari seluruh gedung yang ada dipilih satu gedung yang mewakili berdasarkan jumlah penghuni, kepadatan aktivitas, dan kemudahan dalam pengambilan sampel. Berdasarkan survei pendahuluan, ada beberapa gedung dengan outlet air bekas yang tertutup oleh saluran drainase sehingga menyulitkan dalam pengambilan sampel. Lokasi dan waktu pengambilan sampel air buangan domestik dapat dilihat pada Tabel 1.

Penelitian sebelumnya telah dilakukan di kawasan domestik Padang Utara [5], serta di kawasan institusi dan komersil Padang Utara [6]. Dari penelitian ini didapatkan bahwa fluktuasi air buangan setiap harinya tidak berbeda jauh. Dalam penelitian ini pengukuran kuantitas air buangan dilakukan berdasarkan jenis hari dengan pengkategorian, yaitu (1) Hari regular (Senin-Kamis) yang didefinisikan sebagai hari aktif kuliah, tanpa adanya aktivitas khusus seperti sholat Jum'at, (2) Hari khusus (Jum'at) diklasifikasikan sebagai hari khusus disamping merupakan hari aktif perkuliahan, juga terdapat kegiatan sholat Jum'at serta jam kerja yang lebih pendek (3) Hari libur (Sabtu-Minggu) yang didefinisikan sebagai hari tanpa adanya kegiatan perkuliahan.

Debit rata-rata $\left(\mathrm{q}_{\mathrm{r}}\right)$ adalah debit yang didapatkan dari rata-rata fluktuasi air buangan selama jam aktif, sedangkan debit puncak $\left(\mathrm{q}_{\mathrm{p}}\right)$ merupakan debit tertinggi dalam satu jam. Pengukuran debit berdasarkan jenis hari dilakukan hanya untuk menentukan debit air bekas (grey water), sedangkan untuk air buangan khusus dilakukan hanya satu hari pada saat adanya kegiatan praktikum yaitu hari reguler, demikian juga pengukuran air kotor (black water) juga dilakukan satu hari pada hari reguler. 
Tabel 1. Lokasi dan waktu sampling air buangan domestik

\begin{tabular}{|c|c|c|}
\hline Sumber Air Buangan & Lokasi Terpilih & Waktu (WIB) \\
\hline \multirow[t]{2}{*}{ Asrama mahasiswa } & Menpera I (putri) & $00.00-23.00$ \\
\hline & Menpera II (putra) & \\
\hline \multirow[t]{2}{*}{ Gedung perkuliahan } & Gedung D & $07.00-18.00$ \\
\hline & Gedung $\mathrm{G}$ & \\
\hline Fasilitas kemahasiswaan & $\begin{array}{l}\text { Pusat Kegiatan Mahasiswa } \\
\text { (PKM) }\end{array}$ & $07.00-21.00$ \\
\hline \multirow[t]{3}{*}{ Perkantoran/birokrasi } & Fakultas Peternakan & $07.00-17.00$ \\
\hline & Fakultas Ilmu Sosial dan Politik & \\
\hline & Rektorat & \\
\hline Sarana ibadah & Mesjid Nurul Ilmi & $04.00-21.00$ \\
\hline Kafetaria & Business Centre & $07.00-21.00$ \\
\hline Sarana olahraga & Gedung Futsal & $08.00-21.00$ \\
\hline \multirow[t]{4}{*}{ Laboratorium } & Kimia Dasar & $13.00-17.00$ \\
\hline & Bioteknologi & \\
\hline & Biota sumatra & \\
\hline & Nutrisi Ruminansia & \\
\hline Kandang hewan ternak & Kandang sapi perah & $07.00 \& 14.00$ \\
\hline Pool bus kampus & Pool bus kampus & $08.00-10.00$ \\
\hline
\end{tabular}

\section{Prosedur sampling}

Sampling dilakukan dengan bucket method yang mengacu pada ref. [7], yaitu menampung air buangan menggunakan wadah berukuran 1-2 liter tergantung dari besarnya air buangan selama waktu yang ditentukan.

\section{Air bekas (grey water)}

Air bekas dari masing-masing titik sampling ditampung selama 5 menit, kemudian volume air yang tertampung dalam rentang waktu tersebut dicatat setiap lima belas menit sekali. Sampling dilakukan selama jam aktif masing-masing titik sampling. Khusus untuk mesjid, cara sampling diadopsi dari ref. [8] dengan volume air yang digunakan per orang untuk berwudhu. Pertama-tama dipilih 3 orang secara acak, kemudian dicatat lamanya waktu masing-masing berwudhu. Setelah itu tanpa merubah posisi katup kran, air ditampung sesuai dengan waktu yang telah dicatat sebelumnya, kemudian volume air dihitung. Volume dan waktu yang dibutuhkan dari ketiga orang tersebut dirata-ratakan, nilai ini merupakan jumlah air buangan yang dihasilkan perorang untuk berwudhu di mesjid.

\section{Air buangan khusus}

Air buangan dari aktivitas laboratorium, pool bus kampus, dan kandang ditampung selama satu hari. Kemudian volume air dan lamanya waktu pengumpulan air buangan dicatat. Khusus untuk laboratorium, sebelum ditetapkan laboratorium yang akan dipilih terlebih dahulu disebarkan kuesioner yang mencakup pertanyaan mengenai perkiraan air buangan dalam satu hari, parameter yang diperiksa, pereaksi atau zat kimia utama yang digunakan dan pengolahan terhadap limbah cair yang dihasilkan oleh masing-masing laboratorium. Laboratorium dengan aktivitas tertinggi dipilih menjadi sampel yang mewakili laboratorium.

Air kotor (black water)

Kuantitas air kotor ditentukan berdasarkan air bersih yang terpakai oleh pengguna saat menggunakan toilet [5], sehingga diasumsikan bahwa seluruh air yang dipakai menjadi air buangan. Langkah pertama yaitu menampung air bersih pada bak air yang sudah diketahui volumenya. Kemudian dicatat jumlah air bersih yang terpakai per orang dengan mengurangi volume air bersih total dengan volume sisa air yang terpakai. Penelitian dilakukan selama satu hari pada hari reguler saat ada penggunaan toilet. Sebelum pengukuran dimulai pengunjung toilet diinformasikan bahwa setiap orang yang akan masuk agar tidak melakukan kegiatan berwudhu, namun hanya melakukan kegiatan toilet.

\section{Penentuan kuantitas air buangan Kampus Unand}

Kuantitas air buangan Kampus Unand merupakan jumlah keseluruhan air bekas (grey water), air buangan khusus, dan air kotor (black water). Jumlah air bekas dan air buangan khusus yang didapat dari pengukuran di lapangan dikalikan dengan kapasitas gedung. 


\section{Hasil dan Pembahasan \\ Kuantitas Air Bekas (Grey Water)}

Hasil pengukuran air buangan bekas adalah air limbah yang dihasilkan dari air bekas berwudhu, cuci piring, floor drain, dan wastafel. Air limbah ini dihasilkan dari semua fasilitas yang ada di Universitas Andalas.

\section{Asrama Mahasiswa}

Perbandingan debit air bekas rata-rata asrama mahasiswa Menpera I (putri) dan Menpera II (putra) dapat dilihat pada Gambar 1 Debit air bekas hari libur pada asrama Menpera I (putri) sebesar 0,427 liter/detik dan pada asrama Menpera II (putra) sebesar 0,230 liter/detik lebih sedikit daripada hari reguler dan hari khusus. Hal ini disebabkan karena pada hari libur, sebagian besar mahasiswa pulang ke rumah masing-masing dan ada pula yang melakukan kegiatan ekstrakurikuler di luar asrama sepanjang hari. Debit air bekas rata-rata asrama putri Menpera I yaitu 0,459 liter/detik, lebih besar dibandingkan dengan debit air bekas rata-rata asrama putra Menpera II yaitu 0,261 liter/detik. Hal ini disebabkan mahasiswa putri memiliki kebiasaan menggunakan air lebih banyak dibandingkan putra seperti yang terlihat pada Tabel 2 Rata-rata air bekas untuk kategori asrama adalah sebesar 0,363 liter/detik.

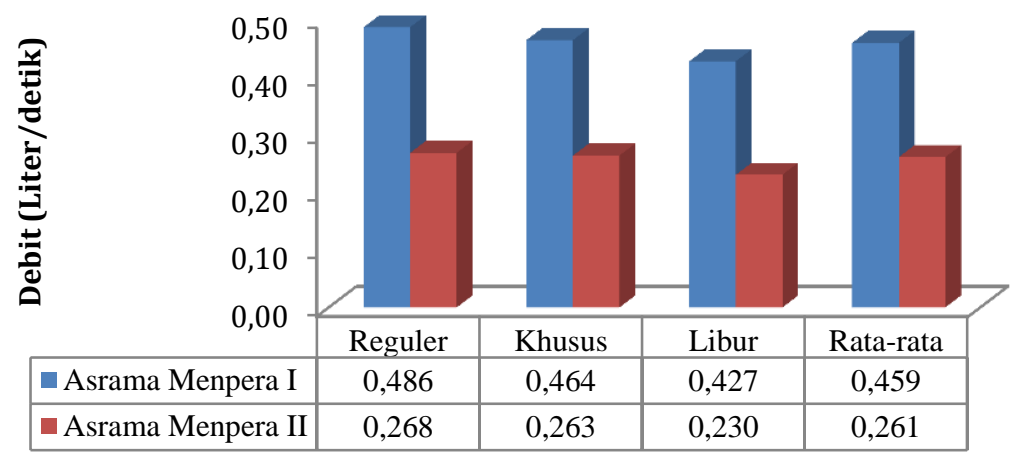

Gambar 1. Debit Air Bekas Asrama Mahasiswa Sumber: Hasil analisis, 2012

Pola fluktuasi air bekas rata-rata Asrama Menpera I dan Menpera II selama 24 jam dapat dilihat pada Gambar 2 Pola fluktuasi cenderung sama antara kedua asrama. Kegiatan mulai tampak pada pukul 04.00 dan debit tertinggi berada dalam rentang pukul 06.00-07.00 yaitu 1,765 liter/detik pada asrama Menpera I dan 0,886 liter/detik pada asrama Menpera II, kemudian mulai menurun pada pukul 08.00 karena sebagian besar mahasiswa berada di luar asrama untuk melakukan kegiatan kuliah. Setelah pukul 12.00 jumlah air bekas kembali meningkat karena beberapa mahasiswa telah kembali ke asrama. Air buangan naik kembali pukul 18.00-20.00 karena mahasiswa melakukan aktivitas mandi dan berwudhu untuk melaksanakan sholat maghrib, kemudian setelah pukul 20.00 jumlah air bekas kembali menurun.

Tabel 2 menunjukkan debit air bekas asrama mahasiswa mahasiswa puteri Menpera I dan asrama mahasiswa putera Menpera II per orang. Debit air bekas perorang pada asrama mahasiswa puteri Menpera I yaitu 116,294 liter/orang/hari lebih banyak dibandingkan asrama mahasiswa putera Menpera II yaitu 108,950 liter/orang/hari. Rata-rata air bekas yang dihasilkan per orang di asrama yaitu 112,622 liter/orang/hari.

Debit rata-rata air bekas asrama Kampus Unand Limau Manis per orang ini lebih rendah jika dibandingkan dengan debit air buangan rumah tangga pada ref. [5] di Kecamatan Padang Utara kategori rumah tangga, dengan debit rata-rata air bekas untuk kategori rumah tangga adalah 191,75 liter/orang/hari, sedangkan debit air buangan asrama adalah 112,752 liter/orang/hari. Hal ini dikarenakan adanya kegiatan yang berbeda pada rumah tangga domestik dengan kegiatan di asrama. Kegiatan di rumah tangga yang tidak ada di asrama yaitu kegiatan seperti menyiram halaman dan mencuci kendaraan, sehingga air buangan yang dihasilkan oleh asrama lebih sedikit. Namun dibandingkan dengan penelitian pada ref. [9], kuantitas air bekas per orang di Swedia adalah 66 liter/orang/hari lebih kecil dibandingkan dengan debit air buangan Kampus Unand Limau Manis. Hal ini dapat disebabkan karena Swedia merupakan negara yang telah maju sehingga memiliki kesadaran dalam penghematan air, sehingga air buangan yang dihasilkan juga rendah. Menurut ref. [10], Swedia merupakan salah satu dari 10 negara yang menggunakan peralatan hemat air (water-efficient equipment) seperti water-efficient washing machine, 
low volume toilet flush, water flow restrictor taps, dan tangki pengumpul air hujan. Alat-alat ini dapat menghemat air sekitar 8-10\%.

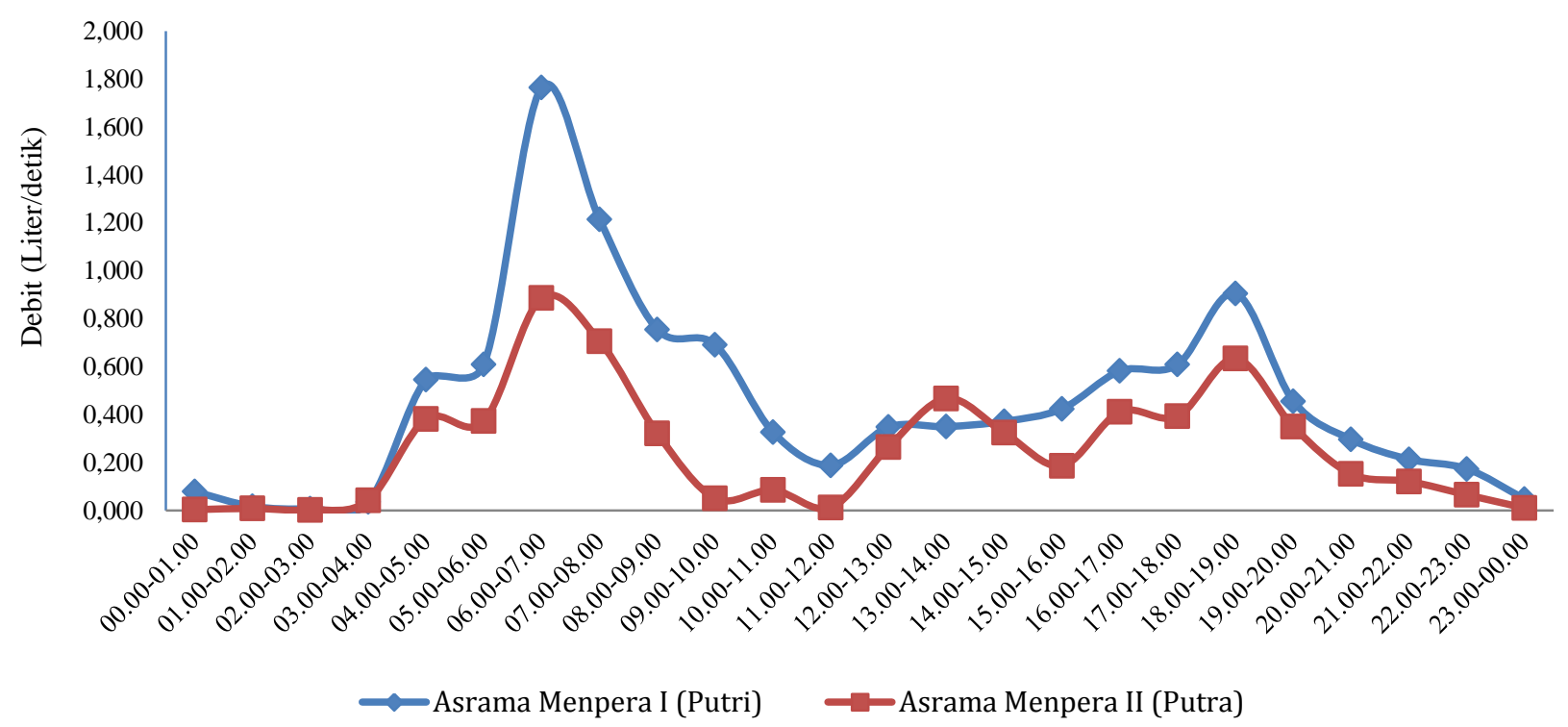

Gambar 2. Perbandingan fluktuasi air bekas asrama mahasiswa Sumber: Hasil analisis, 2012

Tabel 2. Debit air bekas rata-rata asrama mahasiswa Menpera I dan Menpera II per orang

\begin{tabular}{ccc}
\hline Asrama Mahasiswa & Penghuni (orang) & $\begin{array}{c}\text { Debit } \\
\text { (Liter/orang/hari) }\end{array}$ \\
\hline Asrama Mahasiswa Menpera I & 341 & 116,294 \\
Asrama Mahasiswa Menpera II & 207 & 108,950 \\
\hline Rata-rata & 274 & 112,622 \\
\hline
\end{tabular}

Sumber: Hasil analisis, 2012

\section{Gedung Kuliah Bersama}

Aktivitas pada gedung kuliah bersama hanya merupakan kegiatan perkuliahan, sehingga pola fluktuasi air buangan gedung Kuliah D dan G cenderung sama seperti terlihat pada Gambar 3. Air bekas mulai tampak pada pukul 07.00 yaitu 0,043 liter/detik pada Gedung D dan 0,063 liter/detik pada Gedung G, kemudian cenderung stabil dan meningkat sangat tajam dalam rentang pukul 12.00-13.00 hingga 1,290 liter/detik pada Gedung D dan 0,696 liter/detik pada Gedung G. Perbandingan debit air bekas rata-rata gedung kuliah bersama dapat dilihat pada Gambar 4.

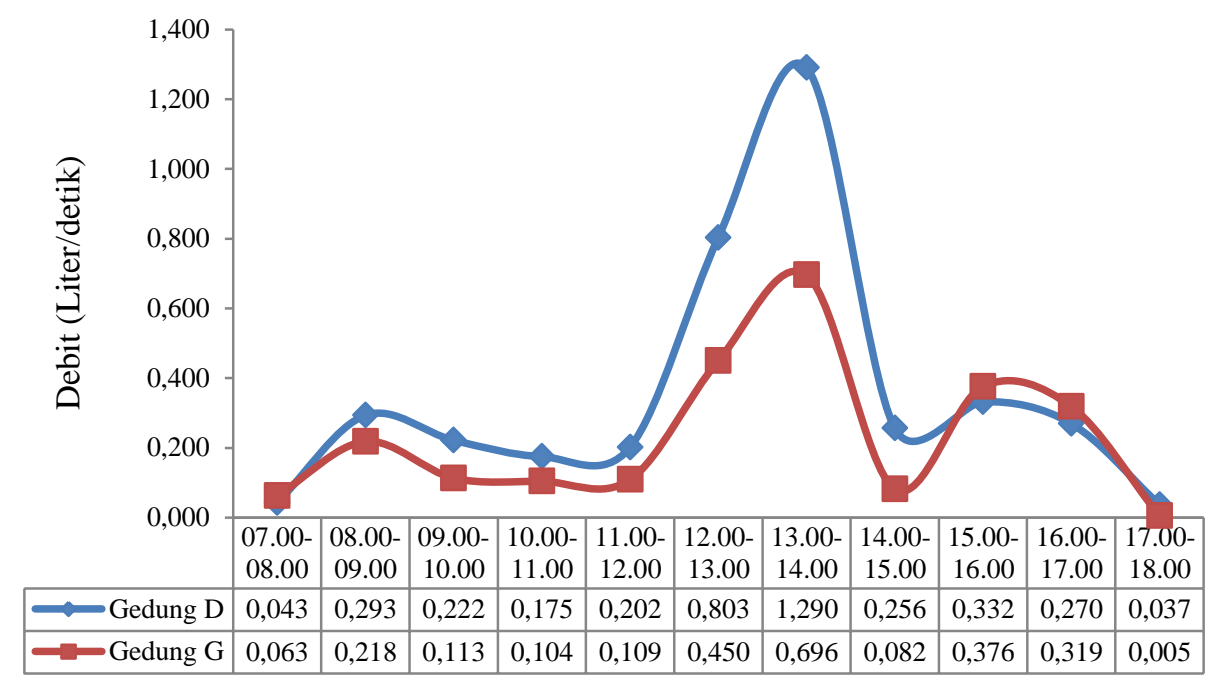

Gambar 3. Fluktuasi air bekas rata-rata gedung kuliah bersama Sumber: Hasil analisis, 2012 


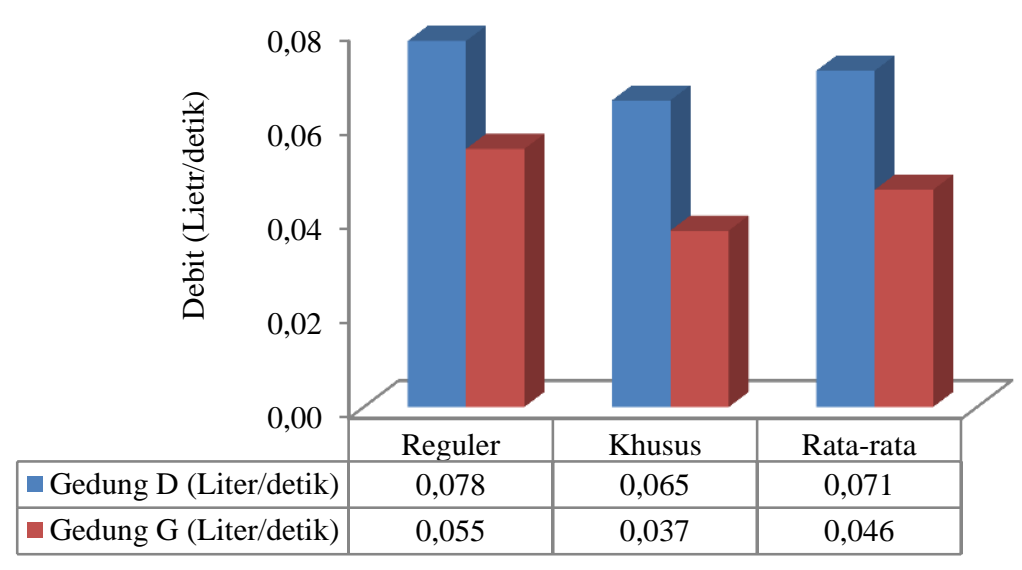

Gambar 4. Debit air bekas gedung kuliah bersama Sumber: Hasil analisis, 2012

Debit air bekas rata-rata gedung kuliah bersama D yaitu 0,071 lebih besar dibandingkan dengan debit air bekas rata-rata gedung kuliah bersama $G$ yaitu 0,046 liter/detik, sedangkan debit rata-rata adalah sebesar 0,059 liter/detik. Jumlah air bekas yang dihasilkan oleh gedung kuliah bersama D lebih banyak dibandingkan dengan gedung kuliah bersama G, dikarenakan pada saat jam puncak, gedung kuliah D lebih banyak menghasilkan air bekas dibandingkan dengan gedung G. Kedua gedung ini memiliki jam puncak tepat pada waktu pelaksanaan sholat dzuhur. Kapasitas ruang sholat gedung kuliah D yang lebih besar membuat mahasiswa lebih banyak melaksanakan sholat dzuhur di gedung ini dibandingkan dengan di gedung $\mathrm{G}$, sehingga air bekas yang dihasilkan dari kegiatan berwudhu di gedung D lebih banyak dibandingkan gedung G. Dari pengamatan di lapangan, pengunjung ruang sholat di gedung D pada saat sholat dzuhur sebanyak \pm 50 orang, sedangkan pengunjung di gedung $\mathrm{G}$ hanya berkisar 20 sampai 30 orang. Berdasarkan jenis hari, debit pada hari khusus yaitu hari Jumat lebih sedikit, yaitu 0,065 liter/detik pada Gedung D dan 0,037 liter/detik pada Gedung G. Untuk kegiatan sholat Jum'at umumnya mahasiswa lebih memilih melaksanakannya di mesjid.

Tabel 3 merupakan perbandingan air bekas gedung kuliah bersama perorangnya. Debit air bekas perorang pada Gedung D lebih banyak, yaitu 25,456 liter/orang/hari dibandingkan Gedung G, yaitu 24,821 liter/orang/hari. Dibandingkan dengan SNI 03-7065-2005 air buangan fasilitas pendidikan adalah 32-64 liter/orang/hari air buangan gedung perkuliahan kampus Unand lebih kecil yaitu 25,139 liter/orang/hari [11].

Tabel 3. Debit air bekas gedung kuliah bersama

\begin{tabular}{lc}
\hline Gedung Kuliah Bersama & $\begin{array}{c}\text { Debit } \\
\text { (liter/orang/hari) }\end{array}$ \\
\hline Gedung D & 25,456 \\
Gedung G & 24,821 \\
Rata-rata & 25,139 \\
\hline \multicolumn{2}{c}{ Sumber: Hasil analisis, 2012 }
\end{tabular}

\section{Gedung Pusat Kegiatan Mahasiswa (PKM)}

Gambar 5 menunjukkan perbandingan debit air bekas rata-rata yang dihasilkan perhari berdasarkan jenis hari. Pada gambar ini terlihat bahwa air bekas yang dihasilkan berkisar 0,086-0,114 liter/detik. Debit air buangan hari reguler dengan hari khusus cenderung sama kecuali pada hari libur. Hal ini disebabkan oleh jumlah pengunjung gedung PKM lebih sedikit pada hari libur dibandingkan dengan hari perkuliahan biasa. Debit rata-rata air bekas untuk gedung PKM adalah sebesar 0,104 liter/detik (11,315 liter/orang/hari).

Air buangan fasilitas kemahasiswaan PKM yang merupakan pusat kegiatan mahasiswa dengan berbagai macam aktivitas di dalamnya, sehingga air buangan gedung ini dibandingkan dengan kategori perkumpulan sosial yang menurut [12] air buangannya 27 liter/orang/hari, maka hasil dari penelitian lebih kecil. 


\section{Perkantoran}

Pola fluktuasi Fakultas Peternakan, FISIP, dan Rektorat cenderung sama, yaitu kegiatan mulai pada pukul 07.00 dan debit puncak terjadi pukul 12.00-13.00 yang merupakan jam istirahat sehingga penghuni gedung melakukan aktivitas makan siang dan berwudhu untuk melaksanakan sholat dzuhur. Debit puncak pada Fakultas Peternakan yaitu 0,102 liter/detik, FISIP 0,056 liter/detik, dan Rektorat 0,268 liter/detik. Setelah pukul 14.00 debit cenderung menurun dan sedikit meningkat pada pukul 16.00 yang merupakan waktu sholat ashar. Perbandingan fluktuasi perkantoran/birokrasi dapat dilihat pada Gambar 6.

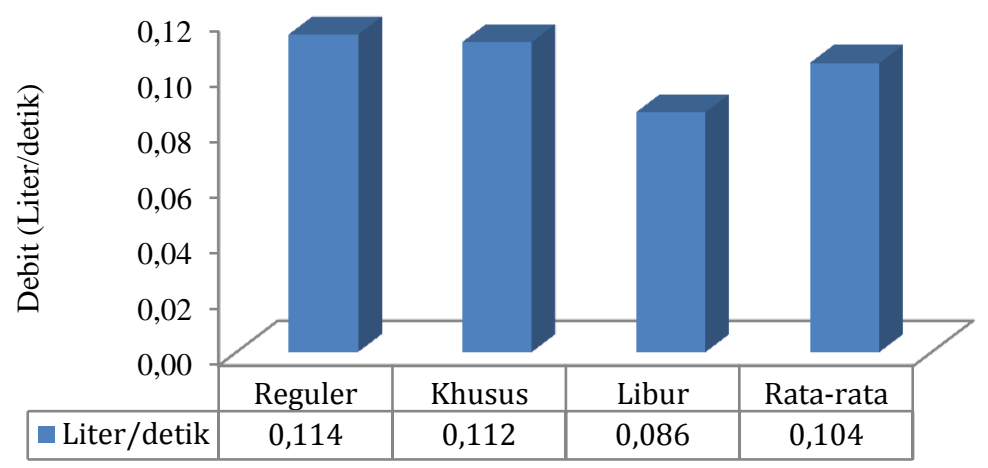

Gambar 5. Debit air bekas gedung PKM berdasarkan jenis hari Sumber: Hasil analisis, 2012

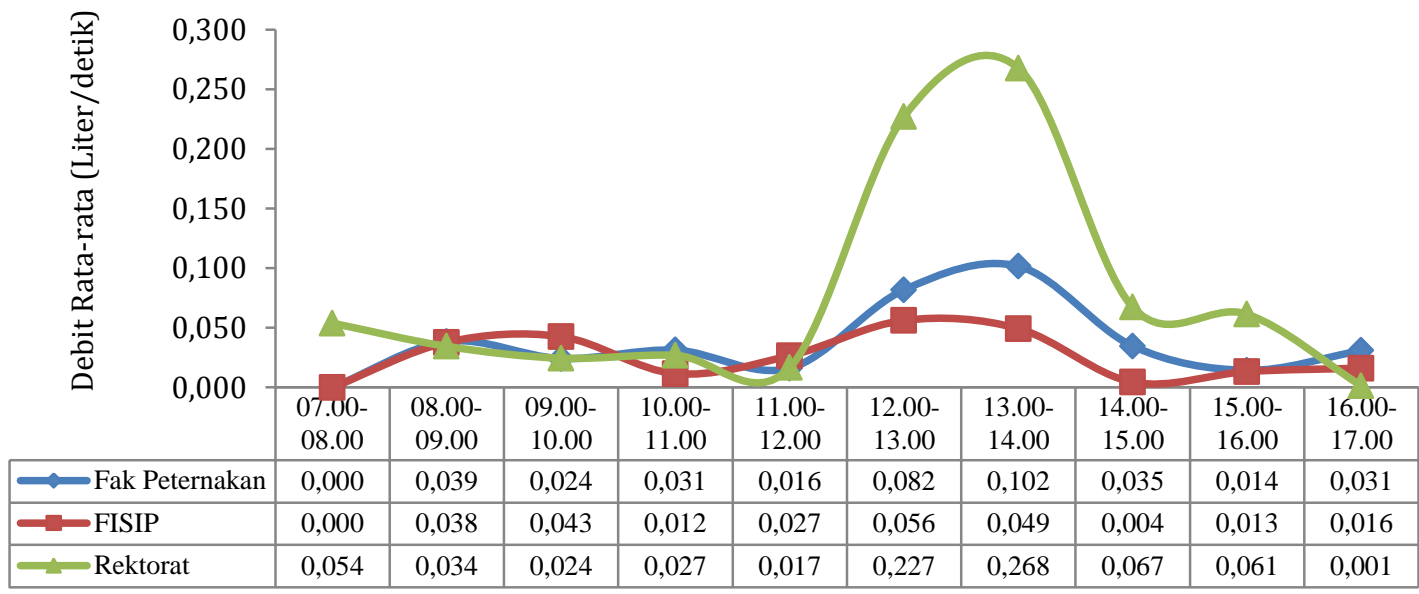

Gambar 6. Fluktuasi air bekas fasilitas perkantoran Sumber: Hasil analisis, 2012

Debit air bekas rata-rata Fakultas Peternakan yaitu 0,034 liter/detik lebih besar dibandingkan dengan debit air bekas rata-rata FISIP yaitu 0,024 liter/detik, dan rektorat yaitu sebesar 0,078 liter/detik, sehingga debit rata-rata air bekas untuk kategori perkantoran adalah sebesar 0,045 liter/detik. Hal ini dapat disebabkan oleh jumlah pegawai rektorat lebih banyak daripada FISIP ataupun Fakultas Peternakan, sehingga jumlah air buangan yang dihasilkanpun lebih besar. Perbandingan air bekas rata-rata perkantoran dapat dilihat pada Gambar 7.

Tabel 4 merupakan perbandingan air bekas gedung kuliah bersama perorang. Air buangan per orang pada rektorat sebesar 34,464 liter/orang/hari lebih banyak dibandingkan dengan Fakultas Peternakan maupun FISIP, sedangkan rata-rata air buangan per orang kategori perkantoran adalah sebesar 33,626 liter/orang/detik. Air bekas perkantoran di Padang Utara berdasarkan [6] yaitu 8,35 - 15,99 liter/orang/hari, jika dibandingkan dengan penelitian tersebut, maka air bekas Kampus Unand Limau Manis yang dihasilkan per orang lebih banyak. Hal ini dapat disebabkan oleh pemakaian air tidak hanya untuk kegiatan berwudhu, buang air, dan wastafel saja tetapi juga untuk mencuci peralatan makan siang. Namun, jika dibandingkan dengan air buangan perkantoran di kota Bandung berkisar antara 40-50 liter/orang/hari [13], maka air buangan perkantoran/birokrasi di Kampus Unand tidak jauh berbeda. 


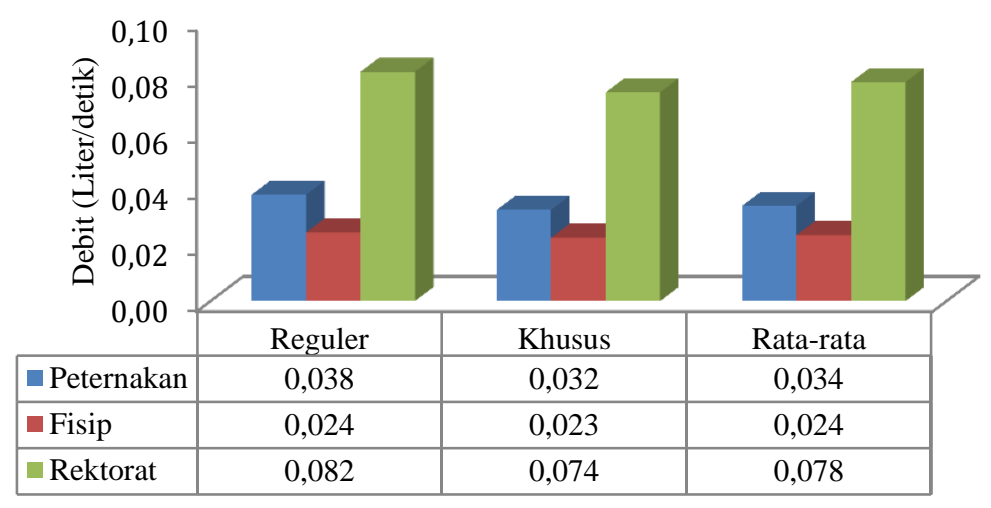

Gambar 7. Debit air bekas rata-rata fasilitas perkantoran Sumber: Hasil analisis, 2012

Tabel 4. Debit air bekas rata-rata perkantoran

\begin{tabular}{lcc}
\hline Gedung Kuliah Bersama & $\begin{array}{c}\text { Kapasitas Gedung } \\
\text { (orang) }\end{array}$ & $\begin{array}{c}\text { Debit } \\
\text { (liter/orang/hari) }\end{array}$ \\
\hline Fak. Peternakan & 174 & 33,119 \\
FISIP & 117 & 33,295 \\
Rektorat & 338 & 34,464 \\
\hline Rata-rata & 210 & 33,626 \\
\hline
\end{tabular}

Sumber: Hasil analisis, 2012

\section{Mesjid Nurul Ilmi}

Perbandingan debit yang dihasilkan berdasarkan jenis hari Mesjid Nurul Ilmi dapat dilihat pada Gambar 8. Air bekas yang dihasilkan pada hari khusus yaitu hari Jum'at paling banyak, yaitu sebesar 0,060 liter/detik, sedangkan debit rata-rata air bekas untuk Mesjid Nurul Ilmi adalah sebesar 0,049 liter/detik.

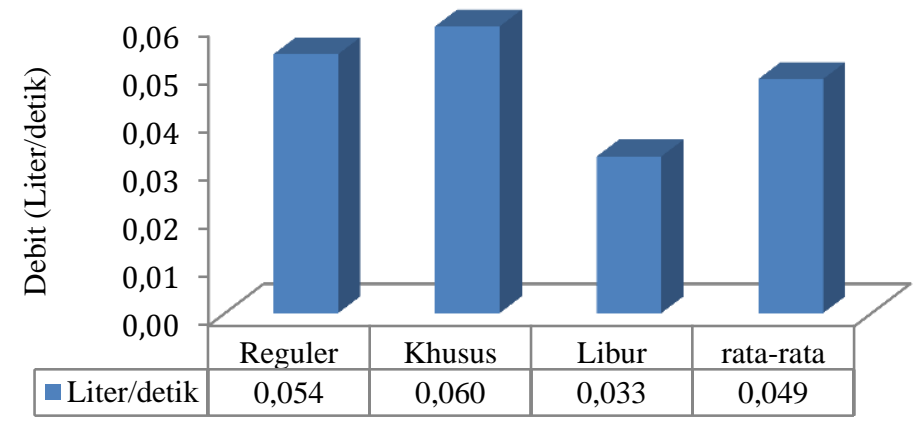

Gambar 8. Debit air bekas Mesjid Nurul Ilmi berdasarkan jenis hari Sumber: Hasil analisis, 2012

Penelitian lain pada mesjid oleh ref. [8] di Yaman diperoleh sebesar 0,003 liter/detik (2.600 liter/hari), lebih kecil dibandingkan hasil penelitian pada mesjid Nurul Ilmi Kampus Unand. Air buangan Mesjid Nurul Ilmi Kampus Unand yaitu 0,049 liter/detik (4.233,6 liter/hari). Penggunaan air dalam berwudhu di Yaman yaitu sebesar 2,7 liter/orang/hari lebih kecil dibandingkan dengan Kampus Unand Limau Manis sebesar 5,4 liter/orang/hari. Hal ini diperkirakan karena Yaman termasuk negara yang sebagian besar wilayahnya gurun pasir, sehingga sumber air terbatas. Penelitian lainnya oleh [14] di mesjid Kampus Universitas Indonesia mengungkapkan bahwa penggunaan air untuk berwudhu per orangnya lebih besar daripada mesjid di Kampus Unand adalah 11,3 liter/orang/hari. Dalam proses berwudhu, keran biasanya dibiarkan mengalir sehingga banyak air yang baik terbuang dalam proses tersebut dan dapat dikatakan bahwa sekitar setengah dari air keran mengalir langsung ke saluran tanpa kontaminasi [15] [16]. Kondisi tersebut akan berpengaruh terhadap kuantitas air buangan yang dihasilkan. 


\section{Kafetaria}

Air bekas yang dihasilkan kafetaria pada hari libur, yaitu 0,273 liter/detik lebih besar dibandingkan hari regular dan hari khusus, karena pada hari libur ini mahasiswa melakukan kegiatan ekstrakurikuler, yaitu Bina Bakat Minat dan Kepemimpinan (BBMK) mulai dari pukul 08.00-16.00 WIB. Pada jam makan siang sampai sore hari mahasiswa lebih makan di kafetaria ini dibandingkan pada saat hari kuliah biasa. Aktivitas BBMK mahasiswa yang berpusat di gedung PKM menjadikan kafetaria BC ramai dikunjungi pada jam makan siang. Selain itu, kafetaria BC merupakan satu-satunya kafetaria yang beroperasi pada hari libur. Debit rata-rata kafetaria yaitu 0,253 liter/detik. Perbandingan debit antara ketiga jenis hari, dan debit rata-rata dapat dilihat pada Gambar 9.

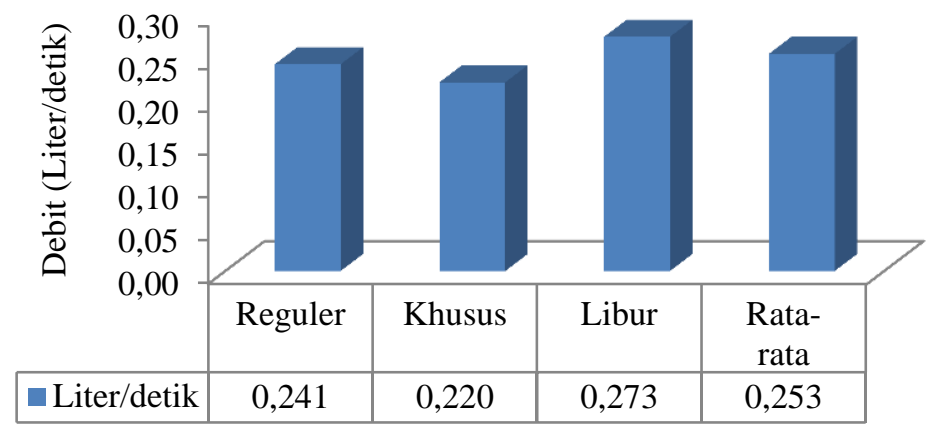

Gambar 9. Debit air bekas rata-rata Kafetaria BC berdasarkan jenis hari Sumber: Hasil analisis, 2012

Setiap hari kafetaria ini dikunjungi sekitar 400 orang mahasiswa, sehingga air buangan yang dihasilkan perpengunjung adalah 54,648 liter/orang/hari. Dibandingkan dengan hasil penelitian air buangan kategori restoran kecil di Padang Utara [6] yaitu 91,53-160,14 liter/orang/hari, maka debit air buangan kafetaria BC lebih kecil. Kegiatan persiapan memasak, pencucian dan fasilitas lainnya di restoran dibandingkan dengan kafetaria yang berbeda menyebabkan pemakaian air di restoran lebih besar dibandingkan dengan kegiatan di kafetaria, sehingga air buangan yang dihasilkan pun lebih besar.

\section{Gedung Futsal}

Air bekas yang dihasilkan gedung futsal pada hari libur adalah yang paling banyak, yaitu 0,082 liter/detik, karena pada hari libur ini lebih banyak mahasiswa yang berlatih futsal. Rata-rata air bekas yang dihasilkan gedung futsal adalah 0,078 liter/detik. Debit air bekas gedung futsal dapat dilihat pada Gambar 10. Air buangan yang dihasilkan perpengunjung adalah 20,39 liter/orang/hari. Jika dibandingkan dengan kategori perkumpulan sosial menurut [12] menghasilkan air buangan 27 liter/orang/hari tidak jauh berbeda dengan hasil yang diperoleh pada penelitian ini.

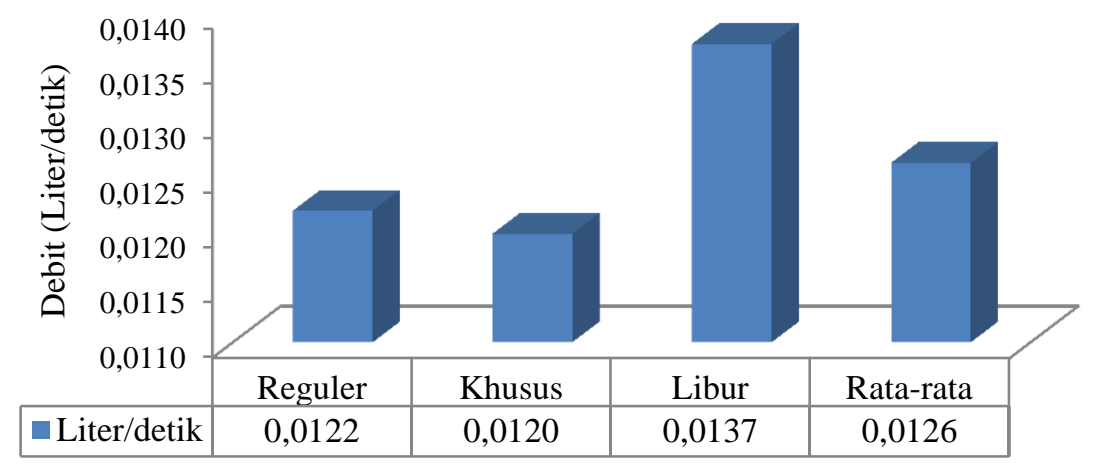

Gambar 10. Debit air bekas gedung futsal berdasarkan jenis hari Sumber: Hasil analisis, 2012

\section{Kuantitas Air Buangan Khusus}

Kategori air buangan khusus adalah air limbang yang berasal dari air limbah laboratorium, kandang hewan dan pool bus kampus. Air limbah dari kegiatan ini mempunyai karakteristik yang berbeda dari air 
limbah grey dan black water yang berasal dari kegiatan fasilitas lainnya yang berada di kampus Unand yang termasuk kategori air limbah domestik.

\section{Laboratorium}

Air buangan yang berasal dari laboratorium merupakan limbah sisa praktikum dan hasil bilasan pencucian alat-alat praktikum. Pada Gambar 11 dapat dilihat perbandingan air buangan yang dihasilkan oleh laboratorium. Debit rata-rata air buangan laboratorium sebesar 327 liter/hari, dengan debit paling besar yaitu yang dihasilkan Laboratorium Biota Sumatra sebesar 532 liter/hari, sedangkan yang paling sedikit adalah Laboratorium Bioteknologi sebesar 126,4 liter/hari.

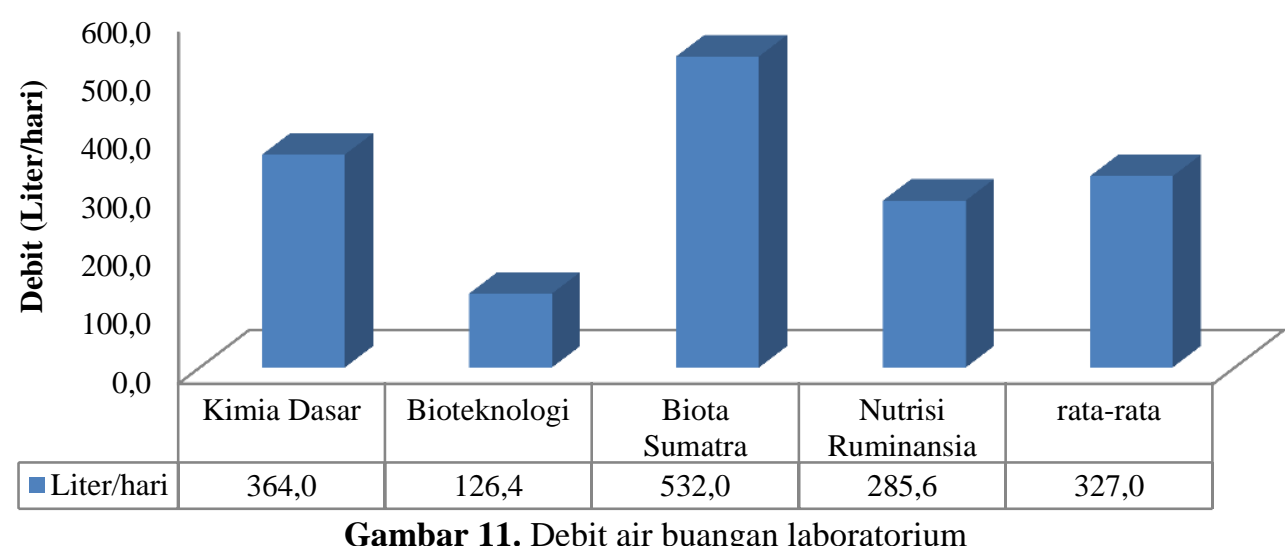

Sumber: Hasil analisis, 2012

Laboratorium Biota Sumatra merupakan laboratorium dengan aktivitas paling padat sehingga banyak memakai air ketika pencucian alat. Laboratorium Bioteknologi menghasilkan air buangan paling sedikit ketika melaksanakan praktikum dikarenakan alat-alat yang digunakan pada praktikum dalam ukuran kecil, sedangkan bahan-bahan yang digunakan dalam jumlah sangat sedikit, sehingga air yang digunakan untuk pencucian juga lebih sedikit dibandingkan dengan ketiga laboratorium lainnya.

Laboratorium di Kampus Unand Limau Manis memiliki jumlah staf rata-rata 2 orang, sehingga air buangan yang dihasilkan adalah 163,500 liter/staf/hari. Menurut Ref. [12], jumlah air buangan laboratorium adalah 120 liter/staf/hari. Jumlah air buangan laboratorium di Kampus Unand Limau Manis tinggi. Hal ini disebabkan oleh kegiatan di dalam laboratorium yang padat tidak hanya oleh praktikum, tetapi juga padat dengan adanya aktivitas penelitian oleh mahasiswa yang menjalani tugas akhir kuliah.

\section{Kandang}

Jumlah air buangan yang dihasilkan kandang pada pagi dan siang hari berbeda (Tabel 5). Kegiatan pembersihan di siang hari lebih lama daripada pagi hari karena pada siang hari dilakukan pembersihan secara menyeluruh. Pada pagi hari hanya dilakukan pemandian hewan ternak, sedangkan pada siang hari tidak hanya dilakukan pemandian hewan ternak, tetapi juga kandang dibersihkan. Oleh karena itu, pada siang hari jumlah air buangan yang dihasilkan lebih banyak yaitu 16.156,8 liter/hari dibandingkan pagi hari yaitu 5.443 liter/hari). Air buangan rata-rata yang dihasilkan kandang dalam satu hari adalah sebesar 10.800 liter/hari.

Tabel 5. Jumlah air buangan kandang sapi perah

\begin{tabular}{cccc}
\hline \multirow{2}{*}{ Waktu } & Lama & \multicolumn{2}{c}{ Debit Air Buangan } \\
\cline { 2 - 4 } & Pembersihan & liter/detik & liter/hari \\
\hline Pagi & 1 jam & 0,063 & $5.443,2$ \\
Siang & 3 jam & 0,187 & $16.156,8$ \\
\hline Rata-rata & & 0,125 & 10.800 \\
\hline
\end{tabular}

Sumber: Hasil analisis, 2012

\section{Pool Bus Kampus}

Berdasarkan keterangan dari petugas pool bus kampus, setiap harinya jumlah rata-rata bus yang dicuci adalah 2 buah bus. Pool bus kampus dapat digolongkan dengan kegiatan bengkel. Pada penelitian yang dilakukan oleh Ref. [6], di Padang Utara diperoleh jumlah air buangan aktivitas bengkel adalah 108,48 liter/hari, sedangkan air buangan pool bus Kampus Unand Limau Manis adalah 1.987,2 liter/hari. Air buangan yang dihasilkan pool bus Kampus Unand Limau Manis sangat tinggi dibandingkan 
penelitian tersebut karena aktivitas di dalamnya terkonsentrasi pada pencucian bus dengan ukuran volume yang lebih besar dari kendaraan biasa. Sementara itu, bengkel di Padang Utara penanganannya pada kendaraan biasa yang ukurannya lebih kecil dibandingkan bus, dan penanganan tidak terfokus ke pencucian melainkan pada perbaikan mesin. Gambar 12. menunjukkan fluktuasi air buangan yang dihasilkan pool bus kampus, dengan air buangan setiap hari hampir sama berkisar 1.382,4-2.505,6 liter/hari. Hal ini disebabkan jumlah dan tipe bus yang dicuci setiap hari juga hampir sama.

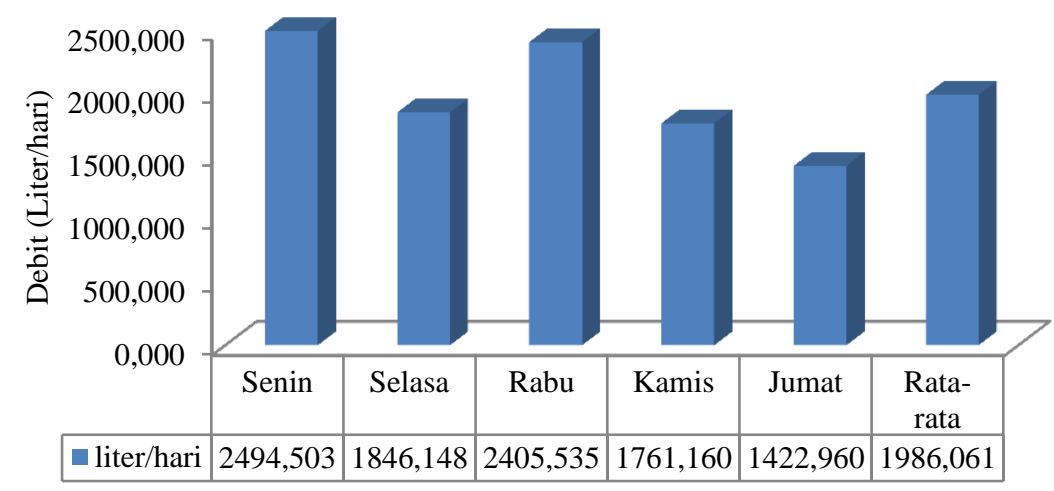

Gambar 12. Fluktuasi air buangan pool bus kampus Sumber: Hasil Analisis

\section{Kuantitas Air Kotor (Black Water)}

Kuantitas air kotor ditentukan berdasarkan data pemakaian air bersih untuk kegiatan toilet dengan mengasumsikan bahwa seluruh air yang dipakai menjadi air buangan. Dari hasil pengukuran diperoleh debit air kotor sebesar 14,6 liter/orang/hari. Dibandingkan dengan data [18] bahwa kapasitas air untuk menggelontor toilet adalah 6-23 liter/orang/hari, maka hasil penelitian ini berada dalam rentang tersebut. Nilai ini juga berada pada kisaran penelitian [6] yaitu 1-30 liter/orang/hari.

Pada Gambar 12, dapat dilihat bahwa pemakaian air untuk toilet paling banyak adalah pada saat pukul 11.00-13.00 WIB yaitu mencapai 52,4 liter, karena waktu ini merupakan waktu istirahat perkuliahan, sehingga banyak pengunjung toilet pada jam ini.

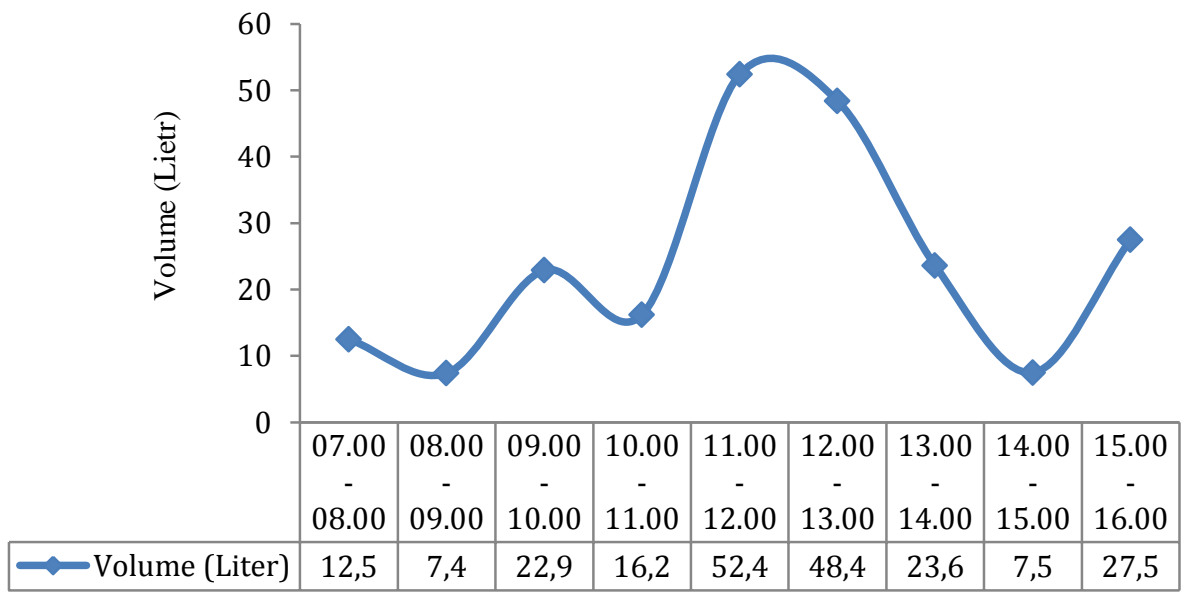

Gambar 12. Fluktuasi air kotor Kampus Unand Sumber: Hasil analisis, 2012

\section{Rekapitulasi Air Buangan Total}

Rekapitulasi debit air buangan Kampus Unand Limau Manis merupakan penjumlahan air bekas (grey water), air buangan khusus, dan air kotor (black water). Tabel 6 merupakan rekapitulasi debit air buangan total Kampus Unand Limau Manis. Debit air buangan rata-rata yang didapatkan dari masingmasing kategori sumber air buangan dikalikan dengan kapasitas pengunjung di masing-masing gedung tersebut.

Debit total air buangan Kampus Unand Limau Manis adalah sebesar $1.439 \mathrm{~m}^{3} / \mathrm{hari}$, dengan ratarata air buangan per orangnya adalah 65,780 liter/orang/hari, jika diperkirakan $80 \%$ sivitas akademika berada di kampus Unand. Jika kuantitas air buangan tersebut dibandingkan dengan kebutuhan air bersih 
menurut SNI 03-7065-2005 yaitu 80 liter/orang/hari, maka rasio air buangan Kampus Unand adalah sebesar $88,75 \%$. Rasio ini tergolong tinggi, karena menurut ref. [18] rasio air buangan yaitu berkisar 50$80 \%$ dan menurut Ref. [17], rasio air buangan berkisar 60-90\%.

Pada Gambar 13 dapat dilihat bahwa air bekas merupakan penyumbang air buangan terbesar dibandingkan dengan air buangan khusus maupun air kotor yaitu 52,65\%, sedangkan air buangan khusus $23,88 \%$ dan air kotor 23,45\% dari total air buangan yang dihasilkan Kampus Unand Limau Manis. Nilai ini tidak jauh berbeda dengan penelitian di kota-kota Amerika Utara bahwa perbandingan antara air bekas dengan air kotor yaitu 73,3\% dan 26,7\% [19] dan di kawasan domestik Irlandia sebesar 73\% dan 27\% [20].

Tabel 6. Rekapitulasi air buangan Kampus Unand

\begin{tabular}{|c|c|c|c|c|c|c|c|c|c|}
\hline \multirow{2}{*}{$\begin{array}{c}\text { Air } \\
\text { Buangan }\end{array}$} & \multirow[t]{2}{*}{ Jenis Fasilitas } & \multicolumn{2}{|c|}{ Kapasitas } & \multicolumn{2}{|c|}{ Air Bekas } & \multicolumn{2}{|c|}{ Air Kotor } & \multicolumn{2}{|c|}{ Air Buangan Total } \\
\hline & & Jumlah & Unit & L/u/hari & L/hari & $\mathrm{L} / \mathrm{o} / \mathrm{hari}$ & L/hari & L/hari & $\mathrm{m}^{3} /$ hari \\
\hline Air Bekas & Asrama & 1671 & Orang & 112,752 & 188.408 & 14,6 & 24.396 & 212.805 & 212 \\
\hline & $\begin{array}{l}\text { Gedung Kuliah } \\
\text { Bersama }\end{array}$ & 12358 & Orang & 25,139 & 310.662 & 14,6 & 180.426 & 491.089 & 491 \\
\hline & Gedung PKM & 1250 & Orang & 11,315 & 14.144 & 14,6 & 18.250 & 32.394 & 32 \\
\hline & $\begin{array}{l}\text { Perkantoran/bir } \\
\text { okrasi }\end{array}$ & 5090 & Orang & 33,626 & 171.158 & 14,6 & 74.314 & 245.472 & 245 \\
\hline & Mesjid & 2520 & Orang & 5,4 & 13.608 & 14,6 & 36.792 & 50.400 & 50 \\
\hline & Kafetaria & 2520 & Orang & 54,648 & 137.712 & - & - & 137.712 & 137 \\
\hline & Futsal & 250 & Orang & 20,39 & 5.097 & 14,6 & 3.650 & 8.747 & 8 \\
\hline Air & Laboratorium & 1725 & Orang & 163,5 & 282.037 & - & - & 282.037 & 282 \\
\hline Buangan & Kandang & 20 & Ekor & 1350 & 27.000 & - & - & 27.000 & 27 \\
\hline Khusus & $\begin{array}{l}\text { Pool Bus } \\
\text { Kampus }\end{array}$ & 35 & Buah & 993,031 & 34.756 & - & - & 34.756 & 34 \\
\hline \multicolumn{6}{|c|}{ Total } & & & 1.439 .386 & 1.439 \\
\hline
\end{tabular}

Sumber: Hasil analisis, 2012
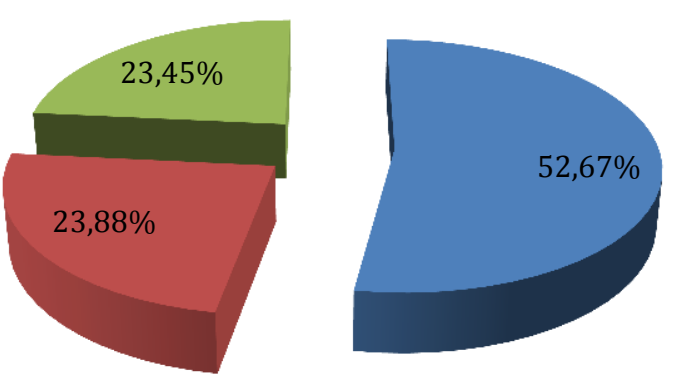

Air Bekas

(Grey Water)

Air Buangan

Khusus

Air Kotor

(Black Water)

Gambar 13. Komposisi air buangan Kampus Unand Sumber: Hasil analisis, 2012

\section{Kesimpulan}

Berdasarkan penelitian yang telah dilakukan diperoleh debit air buangan Kampus Unand Limau Manis yang dihasilkan adalah 1.439,37 $\mathrm{m}^{3} /$ hari dengan rata-rata air buangan perorangnya adalah 65,780 liter/orang/hari. Komposisi air buangan terbesar berasal dari air bekas (grey water) 52,67\%, sedangkan persentase air buangan khusus adalah 23,45\% dan air kotor (black water) adalah 23,88\%. Sebagian besar air buangan berasal dari gedung perkuliahan, perkantoran dan laboratorium. Jam puncak umumnya terjadi pada pukul 12.00-14.00, kecuali pada kafetaria pada pukul 10.00-11.00 dan asrama pada pukul 06.0008.00. Jam puncak dipengaruhi oleh waktu-waktu beribadah dan persiapan menjelang dilakukannya suatu aktivitas kegiatan. Debit puncak diperoleh sebesar 0,022 liter/detik - 1,291 liter/detik dengan faktor puncak air buangan berkisar pada 1,567-3,131.

\section{Referensi}

[1] Peraturan Rektor Universitas Andalas No.13. 2016. Rencana Strategis Bisnis Universitas Andalas 2015-2019.

[2] Kementerian Lingkungan Hidup dan Kehutanan Republik Indonesia. 2016. PermenLH 68 Tahun 2016 - Baku Mutu Air Limbah Domestik. 
kalimantan.menlhk.go.id/index.php/public/page/download/1162.

[3] Leni, "Karakteristik Air Buangan Kampus Universitas Andalas (Unand) Limau Manis, Padang," Tugas Akhir Jurusan Teknik Lingkungan Universitas Andalas, 2013.

[4] Eliasson, John, Rule Development Committee Issue Research Report:Septic Tank Effluent Values, Washington State Department of Health, 2004.

[5] Vonalia, T, "Estimasi Kuantitas Air Buangan Domestik Kecamatan Padang Utara Kategori Rumah Tangga. Padang." Tugas Akhir Jurusan Teknik Lingkungan Universitas Andalas, 2003.

[6] Komala, Puti Sri, Budhi Primasari, Army Kirana, and Fitria Sari. "Penentuan Kuantitas Air Buangan Fasilitas Institusi Dan Komersil Kecamatan Padang Utara Kota Padang." TeknikA 19(1): 26-36, 2012.

[7] Devotta, Sukumar, National Environmental Engineering Research Institute Greywater Reuse in Rural Schools, Guidance Manual, 2007.

[8] Al-Mughalles, M. Hasan, Rakmi Abdul Rahman, Fatihah Binti Suja', and Sharifah Mastura Syed Abdullah, "Mosque Greywater Quantity in Sana'a, Yemen," Electronic Journal of Geotechnical Engineering, 17 K (Bank): 1593-1603. 2012, 2008.

[9] Palmquist, Helena, and Jörgen Hanæus. "Hazardous Substances in Separately Collected Grey- and Blackwater from Ordinary Swedish Households." Science of the Total Environment 348(1-3): 15163. 2005.

[10] Millock, Katrin, and Céline Nauges. "Household Adoption of Water-Efficient Equipment: The Role of Socio-Economic Factors, Environmental Attitudes and Policy." Environmental and Resource Economics 46(4): 539-65. 2010.

[11] Standar Nasional Indonesia, "Tata Cara Perencanaan Sistem Plambing." Standar Nasional Indonesia (SNI)-03-7065-2005.

[12] Morimura dan Noerbambang, Perancangan Dan Pemeliharaan Sistem Plambing. Edisi 4, Pradnya Paramita, Jakarta, 2000.

[13] Va, Vandith, "The Fluctuation of Domestic Wastewater Discharged From Office Building," International Journal of GEOMATE, 17(59), 2019.

[14] Rahmawati, Indah, "Analisis Efisiensi Pemanfaatan Air Untuk Berwudhu (Studi Kasus : Mushola Gedung Departemen Teknik Sipil UI)," Universitas Indonesia, 2009.

[15] Zaied, Roubi A, "Water Use and Time Analysis in Ablution from Taps," Applied Water Science 7(5): 2329-36, 2017.

[16] Bahagia, dan Muhammad Nizar. "Analisis Pengelolaan Air Bekas Wudhu' Jamaah Mesjid Jamik Lambaro Kabupaten Aceh Besar." Serambi Engineering, III(1), 2018

[17] Tchobanoglous, George Burton, Franklin Stensel, and H. David Louis, Wastewater Engineering: Treatment Disposal Reuse, 4 th Edition. McGraw-Hill Education, 2003.

[18] Davis, Mackenzie L, Water and Wastewater Engineering: Design Principles and Practice. McGraw-Hill Companies, Inc, 2010.

[19] Schneider, Lynn. Rule Development Committee Issue Research Report: Greywater Reuse in Washington State. Washington State Department of Health, 2009.

[20] Li, Zhe, Fergal Boyle, and Anthony Reynolds, "Rainwater Harvesting and Greywater Treatment Systems for Domestic Application in Ireland," Desalination 260(1-3): 1-8, 2010. 